\title{
Precursor Products
}
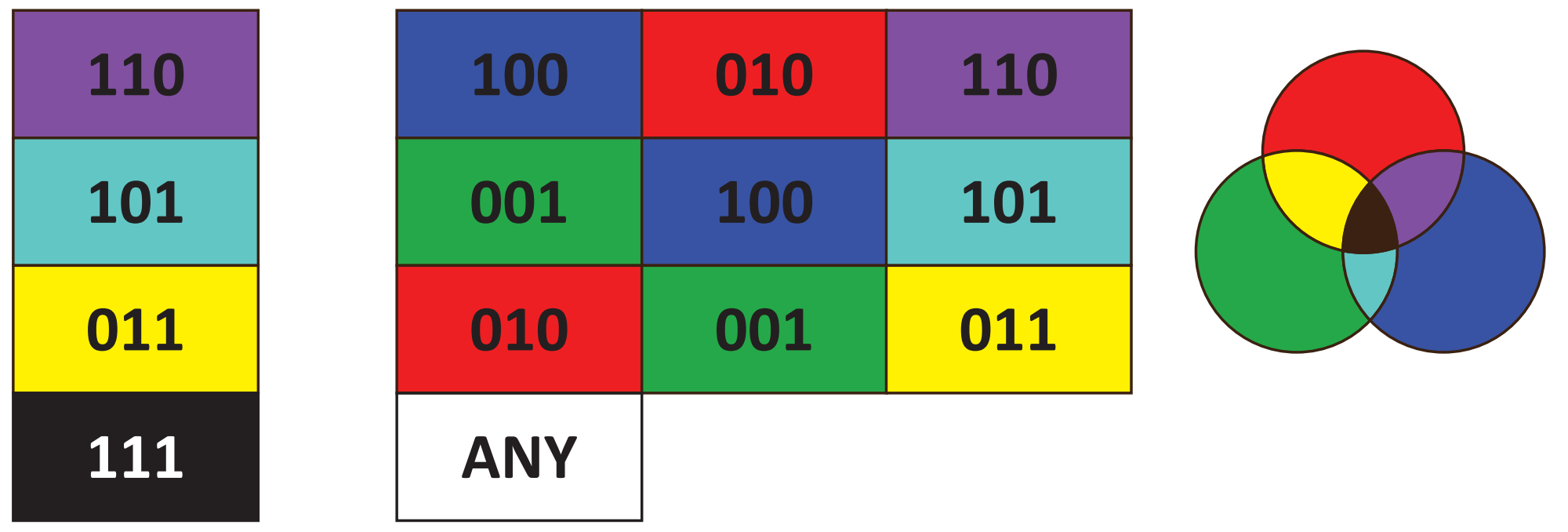